Racial Politics, Resentment, and Affirmative Action: Asian Americans as "Model" College Applicants

Corresponding author:

Michele S. Moses, University of Colorado Boulder

249 UCB, School of Education

Boulder, Colorado 80309

michele.moses@,colorado.edu

@MicheleSMoses

Co-authors:

Daryl J. Maeda, University of Colorado Boulder

339 UCB, Department of Ethnic Studies

Boulder, Colorado 80309

daryl.maeda@colorado.edu

(a)darylmaeda

Christina H. Paguyo, University of Denver

Teaching and Learning

2150 E. Evans Avenue

Anderson Academic Commons Library

Denver, Colorado 80208

christina.paguyo@gmail.com

\begin{abstract}
This article uses philosophical analysis to clarify the arguments and claims about racial discrimination brought forward in the recent legal challenges to affirmative action in higher education admissions. Affirmative action opponents argue that elite institutions of higher education are using negative action against Asian American applicants so that they can admit other students of color instead, using race-conscious affirmative action. We examine the surrounding controversy, positing that the portrayal of Asian Americans as a model minority in this debate foments a politics of resentment that divides racial groups. Our analysis centers on how key concepts such as racial discrimination and diversity may be central to this politics of resentment. Given persistent threats to access and equity in higher education, it is important to gain conceptual clarity about the racial politics of anti-affirmative action efforts.
\end{abstract}

Keywords: affirmative action, Asian Americans, college access, model minority myth, politics of education, race 
Introduction

Affirmative action in selective higher education admissions is being challenged again in the courts and by the federal government. While the case Students for Fair Admissions v. Harvard University $^{l}$ is moving through the court system, the federal Department of Justice is investigating the allegations of discrimination against Harvard. The affirmative action opponents who brought the lawsuit against Harvard contend that academically meritorious Asian American ${ }^{2}$ (and White) applicants are being discriminated against so Harvard can admit underrepresented students of color $^{3}$ instead, using race-conscious affirmative action. In this article, however, we argue that if discriminatory negative action - where race is used as a minus factor in admissions - is being used against Asian American applicants, affirmative action is not to blame. Relatedly, we suggest that many of those blaming affirmative action policy for alleged discrimination against Asian American applicants are using racial politics to set different groups of people of color at odds with each other. This fosters a divisive politics of resentment that then serves to deflect attention from their ultimate goal to dismantle affirmative action in order to safeguard elite college and university spots for White students.

To make this case, we use philosophical inquiry, because as a method it allows an investigation into the claims and concepts central to recent challenges to affirmative action. In addition, given the centrality of race to our arguments, we draw from critical race theory to analyze the controversy surrounding Asian Americans, negative action, and affirmative action. The issue in which we are interested - how Asian American students should be treated in admissions processes - is at heart a normative rather than empirical one, (i.e., centering how persons ought to act and live, and beyond that, for how we justify our actions). College admissions practices 
need to be based on philosophical ideas related to college access and educational opportunity and holistic reviews of applicants' qualifications, and not solely or even primarily on quantitative measures of academic merit or percentages of students (Guinier, 2015; Gutmann, 1999; Moses, 2002). We thus make two primary normative claims regarding the complex relationship between Asian Americans and affirmative action: 1) selective colleges should not discriminate against Asian American applicants or limit their numbers, nor should colleges treat them as if they are all the same; and, 2) Asian American students who feel wronged should not blame raceconscious affirmative action for the negative action that selective institutions of higher education may be perpetrating against them.

\section{A Note on Theory}

Critical race theory (CRT) frames how we understand the complexities of affirmative action, Asian American applicants, and discrimination. Like Teranishi et al., we find CRT to be a valuable framework to use in examining how Asian Americans are positioned in educational institutions (Teranishi et al., 2009). Deriving from critical legal studies, critical race theory helps analyze how power is distributed; in particular it focuses on the interactions between race, racism, and social institutions (Donahoo, 2008). At the same time, we draw on history and philosophy to understand anti-affirmative action strategies past and present. We leverage three tenets from critical race theory to frame our perspectives: the permanence of racism, majoritarian narratives, and counternarratives (Donahoo, 2008; Lynn, Jennings, \& Hughes, 2013; Taylor, Gillborn, \& Ladson-Billings, 1995). Relying on critical race theory, first we recognize that racism is an ordinary and permanent phenomenon deeply embedded within American legal landscapes and cultural practices (Taylor, Gillborn, \& Ladson-Billings, 1995). Racism 
continually erodes the contours of American life: people of color earn less, face exclusionary housing practices, experience racial profiling, remain over-represented in the prison system, and encounter limited access to quality education as well as postsecondary education in comparison to Whites (Alexander, 2012; Andrews \& Tuitt, 2013; Bonilla-Silva, 2010; Collins, 2009). Second, according to critical race scholars, discourses that maintain racism are grounded in majoritarian narratives that explain racial phenomena in individual terms rather than as outgrowths of institutionalized, structural inequalities (Brown \& Jackson, 2013; Taylor, Gillborn, \& Ladson-Billings, 1995). For example, people of color are understood to have lower salaries because they supposedly do not work as hard, receive prison sentences more frequently because they commit more crimes, and so on. These types of majoritarian narrative use concepts such as objectivity and meritocracy to uphold White supremacy. This resonates with research conducted by Park and Liu (2014), articulating how reductive notions of meritocracy appear to join the concerns of Whites and Asian Americans - interest convergence — to allegedly enact justice. Arguably, the notion of Asian Americans as the model minority is another story that bolsters the majoritarian narrative. To identify and disrupt majoritarian narratives, we meet calls from critical race scholars to examine legal phenomena in situ, which enables us to disrupt ahistorical and decontextualized approaches (Delgado \& Stefancic, 2012). Third, we challenge majoritarian devices of neutrality and meritocracy by positioning the expertise and experiences of people of color as legitimate forms of knowledge in counter narratives (Lynn, Jennings, \& Hughes, 2013; Solórzano, Ceja, \& Yosso, 2000). Counternarratives can be further textured by the notion of intersectionality, which provides a more granular and nuanced perspective of looking at intersections of race, gender, sexual orientation, and a myriad of identities (Crenshaw, 1991). Throughout the article, we apply these tenets from critical race theory to examine and 
deconstruct the strategies and narratives generated by the Project on Fair Representation to support its criticisms of race-conscious affirmative action, particularly in the context of its newest legal challenge against Harvard's admissions policies.

Our purpose is to provide a nuanced examination of the potentially competing moral goods that have surfaced within such challenges to affirmative action, to illuminate how key concepts such as racial discrimination, merit, and diversity - which can be opaque and interpreted in conflicting ways - are central to a contemporary politics of resentment developing around selective college admissions (Moses, 2006; Banning, 2006; Takagi, 1993a). In so doing, we take up the normative question of how Asian American students ought to be treated in selective admissions processes given two potentially competing moral goods (i.e., things involving moral ideals that are valuable for relevant persons): 1) educational opportunities for all Asian American students and 2) educational opportunities for Black, Latinx, and Native American students. We challenge the idea that these two goods actually are in conflict. Two central questions guide our analysis. First, how should we understand plaintiffs' discrimination claims in legal challenges to selective colleges' affirmative action policies that are based on charges of unfair treatment of Asian American applicants? And second, what is the relationship between these claims of discrimination and the political strategies employed by critics of race-conscious admissions policies? To answer these questions, we need a rich, expansive understanding of the concept of discrimination - to reconcile challenging negative discrimination against Asian American applicants, while at the same time arguing for positive discrimination in favor of applicants from underrepresented racial and ethnic groups (Hellman, 2008; Kennedy, 2013). 
In what follows, we first define "negative action," a concept that is key to this inquiry, and that may not be understood broadly. Next we set the context for the Harvard case, which was put forward by the Project on Fair Representation, the organization founded by Edward Blum, focusing on relevant legal and political challenges to affirmative action. We then examine the vast diversity of "Asian Americans" as an identity group, positing that Asian Americans are portrayed as a model minority, thus highlighting what critical race theory holds to be majoritarian narratives, which foment a politics of resentment that divides racial groups. Our analysis centers on how concepts such as racial discrimination, merit, and diversity may be central to this politics of resentment brewing around selective college admissions. We lay out and defend what we see as the two key moral claims at stake: 1) discriminating against Asian American college applicants is wrong; and 2) affirmative action does not exacerbate negative action against Asian American students. We argue that the lawsuits and complaints on behalf of Asian American college applicants purport to be fighting discrimination against Asian Americans when instead they are using a narrative of discrimination inappropriately to protect White applicants by eliminating affirmative action in admissions. ${ }^{4}$ The same group organizing the Harvard lawsuit was behind the Fisher v. University of Texas case and has organized a lawsuit against the University of North Carolina on behalf of a White plaintiff, as well as recruiting Asian and White plaintiffs from the University of Texas (Haurwitz, 2017; UT Not Fair). We analyze the complex strategies affirmative action opponents use to foster a politics of resentment by confounding, exploiting, and dividing applicants of color, as they tell what Park and Liu (2014) call "an overly simplistic and incomplete story" of the way Asian Americans are treated by selective institutions using affirmative action (p. 37). ${ }^{5}$ We conclude that abolishing negative action (if it exists) and maintaining affirmative action are compatible aims in the quest 
for nonoppressive college admissions for all students. Given persistent threats to access and equity in higher education, it is important to gain conceptual clarity about the racial politics of anti-affirmative action efforts.

\section{Defining Negative Action}

Liu (2007-2008) defines "negative action" briefly as "the unfavourable treatment of Asian Americans relative to Whites" (p. 391). He bases this on Kang's (1996) more complete definition of negative action as

unfavorable treatment based on race, using the treatment of Whites as a basis for comparison. In functional terms, negative action against Asian Americans is in force if a university denied admission to an Asian American who would have been admitted had that person been White. To be clear, Whites, not any other race, are used as the baseline. (p. 3)

Kidder (2006) calls negative action a "minus factor" for Asian American applicants "relative to White candidates, a practice that is separate and apart from any affirmative action 'plus factor' given to African Americans and Latinos in the admissions process" (p. 605, n. 2). We rely on these definitions herein.

It is important to note at the outset that the question of whether elite institutions of higher education are using discriminatory negative action against Asian American applicants is an empirical question that is beyond the scope of this article. A key concern herein is about how the plaintiffs against Harvard are justifying their complaint against race-conscious affirmative action in admissions, not whether negative action is taking place. Whether there was or was not 
negative action by Harvard admission officials, the lawsuit misplaces the blame for the alleged discrimination on affirmative action policy.

\section{Policy and Legal Context}

The "Harvard University Not Fair" website greets readers with a photo of an Asian American student accompanied by the following text: "Were you denied admission to Harvard? It may be because you're the wrong race" (Harvard University Not Fair). But, what does it mean to be "the wrong race?" The website's depiction of an Asian American as the "wrong race" appears to be an intentional strategy. What does it mean to be "the wrong race?" It implies that because Asian Americans are not Black or Latinx ${ }^{6}$ or Native American, they will experience discrimination due to elite institutions' affirmative action policies. "Students for Fair Admissions" - an arm of the Project on Fair Representation - filed suit against Harvard College on November 17, 2014, on behalf of a Chinese American applicant who had been rejected from Harvard. The lawsuit charges that Harvard's admissions policy violates Title VI of the Civil Rights Act of 1964, which bars federally funded entities from discriminating based on race or ethnicity. This lawsuit, along with the related Department of Justice investigation (Frnaklin \& Zwickel, 2018) and a civil rights complaint by a waitlisted applicant and a small coalition of Asian American organizations bring renewed attention to college admission processes for Asian American and White applicants at selective institutions of higher education such as Harvard and Princeton. ${ }^{7}$ The student plaintiff in the Harvard case was recruited actively by affirmative action opponent Blum, who was also behind Fisher v. University of Texas-Austin (McCloskey, 2014). In addition, the Asian American Coalition for Education made similar discrimination complaints to the United States Department of Education, this time naming Brown, Dartmouth, and Yale Universities (Asian American 
Coalition for Education, 2016). To date, none of the complaints has been found to have merit (Jaschik, 2015), though the Harvard lawsuit is pending.

The United States Supreme Court has repeatedly affirmed that colleges and universities can use race-conscious affirmative action policies in keeping with the law. But those decisions have not resolved the larger moral and political disagreements over affirmative action (Moses, 2016). Indeed, immediately after the Fisher decision, Roger Clegg, president of the Center for Equal Opportunity, which supports colorblind policies, called the decision "only a temporary setback" (Liptak, 2016, para. 6).

The claim of admissions discrimination against Asian American applicants is not new, but it has garnered renewed attention due to the Project on Fair Representation's plaintiff-recruitment campaign (Haurwitz, 2017; Poon, 2009; Takagi, 1993b). This shows that there has been no easy way to reconcile the issues of discrimination, hegemony, privilege, or racism bound up in these complaints. The diverse lived experiences of Asian American students in particular raise significant moral questions, and from a critical race perspective, point to the importance of drawing on the notion of intersectionality to question homogeneous characterizations of racial groups.

The controversy over how Asian Americans are treated in selective college admission was jump started in 2005, when sociologists Espenshade and Chung (2005) published findings from a study they described as investigating the effects of affirmative action bans on the racial and ethnic composition of student bodies at selective colleges and universities. They found that if 
affirmative action were to be eliminated, the acceptance rates for Black and Latinx applicants would likely decrease "by as much as one-half to two-thirds," while the acceptance rate for White applicants would increase by only half a percentage point. But more than that, what they noted was that the acceptance rate for Asian American applicants would increase the most by far, with Asian applicants "occupy[ing] four out of every five seats created by accepting fewer African American and Hispanic students" (pp. 303-304).

This finding has been cited repeatedly to support claims of admissions discrimination (i.e., negative action) against Asian Americans. Indeed, the suit against Harvard cited research from 2009 in which Espenshade, this time with co-author Radford, found that Asian American applicants accepted at selective colleges had higher standardized test scores, on average, than other accepted students.

Yet, in the holistic admissions processes endorsed by the Supreme Court in Grutter v. Bollinger (2003), standardized test scores are not the only, or even the primary, criterion for admission. Holistic review takes many relevant factors into account including academic achievement, of course, but also factors such as a commitment to public service, overcoming difficult life circumstances, achievements in the arts or athletics, or leadership qualities.

So, why would the plaintiff in the Harvard case conclude that the disparities in SAT scores shown by Espenshade and colleagues necessarily indicate that Asian American applicants are being harmed by race-conscious affirmative action? From a critical race perspective, this conclusion comes as no surprise because merit - a majoritarian narrative used to uphold racism 
and White supremacy - is leveraged in this instance. To strengthen this majoritarian narrative, Asian Americans are exploited as a "model minority" whose admissions credentials are used to uphold a certain definition of "merit" characterized by academic accomplishments only. As such, focusing on simplistic ideas about standardized tests as the primary evidence for who "deserves" to be admitted to elite institutions like Harvard may serve to stir up division and resentment among accomplished applicants who get rejected (Guinier, 2015; Kidder, 2006; Takagi, 1993b).

Although Kidder (2006) has pointed out that Espenshade and colleagues did not intend for their research to be used to challenge affirmative action, their findings nevertheless have been used to fuel a divisive politics of resentment among Asian Americans. Kidder (2006) has shown, however, that the interpretations of Espenshade's findings may be called into question because the research itself rests on unproven or faulty assumptions: first, that selective institutions are indeed using negative action against academically accomplished Asian American applicants, and second, that the institutions are using negative action for the purpose of admitting other students of color with lower standardized test scores. Yet, Espenshade himself has said that his findings have been over-interpreted and do not prove that colleges discriminate against Asian American applicants through negative action (Bernhard \& Delwiche, 2015). He noted that his data are incomplete, given the myriad factors that colleges take into account in admissions decisions: "I stop short of saying that Asian-American students are being discriminated against in the college application process because we don't have sufficient empirical evidence to support that claim" (Bernhard \& Delwiche, 2015, para. 9, lines 1-5). 
Nevertheless, the finding that Asian American applicants seem to need a higher SAT score than White applicants or other applicants of color in order to be admitted to a selective college is being cited in legal challenges to affirmative action as proof that elite institutions like Harvard are discriminating against Asian Americans in their admissions processes. Such arguments add further fuel to the fire of anti-affirmative action fights through the majoritarian narrative of meritocracy and the model minority myth. Below, we discuss Students for Fair Admissions v. Harvard University, a civil rights complaint against Princeton alleging unfair discrimination against Asian American applicants (Students for Fair Admissions n.d.), and other relevant court cases.

\section{Students for Fair Admissions v. Harvard University}

Plaintiffs in the Harvard case claim that the university exhibits "invidious discrimination by strictly limiting the number of Asian Americans it will admit each year and by engaging in racial balancing year after year. These discriminatory policies in college admissions are expressly forbidden by the Fourteenth Amendment and federal civil rights laws" (Students for Fair Admissions, n.d.).

Curiously, the lawsuit against Harvard did not counter negative action against Asian Americans; instead it vilified affirmative action ("racial preferences"): "Given what is occurring at Harvard and at other schools, the proper response is the outright prohibition of racial preferences in university admissions - period. Allowing this issue to be litigated in case after case will only perpetuate the hostilities that proper consideration of race is designed to avoid" (Students for Fair Admissions, n.d.). From a critical race perspective, the move to pathologize affirmative action 
exemplifies, once again, how meritocracy is a tool that drives the majoritarian narrative where race has no place in admissions.

The Li Complaint against Princeton

Jian Li brought a Civil Rights Complaint against Princeton University when he was rejected, claiming that Princeton's affirmative action admissions policy benefiting underrepresented students of color of Black, Latinx, and Native American heritage discriminated against Asian American applicants who had stronger academic records. (Li was accepted at and attended Yale.) (Liu, 2007-2008).

Although Li's civil rights complaint against Princeton seems based on the idea that affirmative action is discriminatory against Asian Americans, it differs from the Project on Fair Representation lawsuits because it more broadly includes legacy and athletic preferences as discriminatory as well (Liu, 2007-2008). As Liu (2007-2008) has pointed out, there is a "meaningful distinction" (p. 431) between disputing affirmative action and challenging negative action against a group that is - in general - faring well in selective higher education admissions after having been underrepresented in higher education historically.

Previous Supreme Court Cases Challenging Affirmative Action in Admissions The 1978 decision in the Regents of the University of California, Davis v. Bakke case provided the legal guidelines for current affirmative action policies, which have been updated and solidified by the Grutter v. Bollinger (2003) ruling. The prominent justification for affirmative 
action policies, the diversity rationale, came from Justice Powell's opinion in Bakke (Moses, 2006).

The plaintiff in Grutter was a White applicant who felt that she would have been admitted to the University of Michigan Law School if not for the race-conscious affirmative action used in the institution's admissions decisions. Like the recent Harvard plaintiff, Barbara Grutter maintained that the University of Michigan's use of race as a factor in admissions violated the Equal Protection Clause of the Fourteenth Amendment and Title VI of the Civil Rights Act (Moses, 2016).

Just as the Project on Fair Representation recruited plaintiffs, another anti-affirmative action advocacy organization, the Center for Individual Rights, supplied lawyers for Grutter. In its Grutter ruling the Court affirmed that the educational benefits that emerge when a campus has a diverse student body serve a compelling state interest. The diversity rationale was the central justification in upholding the constitutionality of affirmative action. Writing for the majority in Grutter, Justice O'Connor explained: “The Law School's educational judgment that such diversity is essential to its educational mission is one to which we defer. The Law School's assessment that diversity will, in fact, yield educational benefits is substantiated by respondents and their amici" (Grutter, 2003, p. 328). It follows that affirmative action policies could focus on a range of qualifications for college including applicants' varied experiences and possible contributions to the learning environment, as well as academic performance. The decision underscored the importance of assessing each applicant holistically. 
The most recent lawsuit contesting a White student's rejection to UT-Austin was brought by Abigail Fisher, alleging she was not accepted because of "racial preferences" (Kever, 2008, paragraph 1, line 2). Sponsored by the Project on Fair Representation, Fisher's attorneys argued that, per Grutter, UT-Austin could use affirmative action only if race-neutral alternatives did not succeed in admitting a diverse student body. At UT-Austin, $75 \%$ of the available places for freshmen go to Texans who graduated in the top ten percent of their high school classes. The remaining places are offered after individualized application review, in which race and ethnicity may be considered as qualifying factors. The $5^{\text {th }}$ Circuit Court of Appeals unanimously ruled in favor of UT-Austin in 2011, saying that the admissions policy was in keeping with what the U.S. Supreme Court allowed in Grutter. Fisher appealed that decision to the U.S. Supreme Court. In 2013 the Court affirmed 7-1 that colleges and universities can consider race or ethnicity as factors in admissions decisions. The Court decided to remand the case back to the $5^{\text {th }}$ Circuit, instructing the Court of Appeals to address the issue of strict scrutiny, that is, to examine UTAustin's policy more closely to determine specifically whether the UT-Austin undergraduate admissions policy was indeed narrowly tailored to its goal, as laid out in Grutter. The $5^{\text {th }}$ Circuit then upheld its previous decision, sending Fisher back to the Supreme Court in 2015. Finally, in a landmark judgment on June 23, 2016, the Supreme Court upheld the constitutionality of raceconscious affirmative action in university admissions.

\section{Representing Asian Americans}

By using images of Asian American students to recruit complainants against Harvard and other highly selective institutions of higher education, the Project on Fair Representation relies on the twinned ideas that Asian Americans comprise a monolithic group and that they constitute a 
"model minority." In fact, the term "Asian American" refers to a diversity of Asian ethnicities in the United States, whose educational opportunities and achievements vary widely; it also reinforces how intersectionality creates complexities when considering issues of race. Consider that the 2010 census question on race included check boxes for six Asian groups - Asian Indian, Chinese, Filipino, Japanese, Korean, and Vietnamese — along with a box for "Other Asian," with a prompt for detailed responses such as "Hmong, Laotian, Thai, Pakistani, Cambodian, and so on."

In addition, by casting plaintiffs as meritorious and deserving of - if not entitled to - a spot at an elite university, it also conveys the stereotypical received wisdom about Asian American "model" students who are wronged by race-conscious affirmative action programs (Lee, 1996; $\mathrm{Wu}, 2013)$. It is reductive to challenge affirmative action based on the argument that selective admissions processes are discriminatory against Asian Americans. Such an argument relies on stereotypes about Asian Americans' widespread academic and socioeconomic success in the US.

The next section describes the vast diversity of Asian American communities. We demonstrate that education policies like affirmative action in higher education admissions need to approach Asian American applicants in a holistic way that considers the distinct experiences of the different heritage groups that make up the larger political racial group (Lee, 2008).

The Problematics of "Asian Americans" as an Identity Category The term "Asian American" encompasses a wide diversity of Asian ethnic groups in the United States, whose educational opportunities and achievements vary widely. Asian Americans range 
from fifth-generation Chinese Americans whose ancestors immigrated in the 1850s to firstgeneration Burmese Americans whose families settled in the US as refugees, from workers who arrive with little formal education to those whose bachelor's and advanced degrees enable them to enter the US on preferred $\mathrm{H}-1 \mathrm{~B}$ visas, and from families surviving in poverty to those enjoying wealth. Over the past half-century, the demographics of Asian America have changed dramatically. Chinese, Japanese, and Filipino Americans comprised the vast majority of Asian Americans until 1965. The Immigration Act of 1965 radically altered the size and shape of Asian America by rescinding decades-old anti-Asian immigration restrictions and minuscule quotas (Hing, 1994). Most significantly, it instituted preferences for professionals with desired skills and training, which privileged certain Asian immigrants - primarily medical professionals in the 1970s and high tech workers more recently. The end of the Vietnam War saw an influx of Southeast Asia refugees. The Asian population of the United States ballooned from roughly $321,000(0.2 \%$ of the total population) in 1950 to roughly $17,320,000(5.6 \%)$ in 2010. Concomitantly, the number of ethnic groups subsumed into the category of Asian American proliferated from three in 1950 to 24 in 2010. The growth of the Asian American population resulted from increasing immigration streams that include highly educated professionals, poor workers, and refugees. ${ }^{8}$

Because of the diversity in the structures of incorporation of Asian immigrants, overarching statistics cannot paint a full picture of the mélange that constitutes Asian America (Kao, 1995). Sakamoto, Goyette, and Kim (2009) compiled data showing that in 2005/2006, among Asian Americans aged 25 and older, the percentage holding a bachelor's degree ranged from a high of $68.3 \%$ for Asian Indians to a low of $11.8 \%$ for Laotians. Although the number of years of 
schooling completed averaged 14.1 for all Asian Americans, Cambodians (10.2), Hmong (8.8), and Laotians (10.3) all averaged less than high school completion. Similarly, poverty rates ranged from a high of $29.7 \%$ for Hmong to a low of 6.5\% for Filipinos (p. 258). No definitive statement can be made about the economic status or educational achievements of Asian Americans without deconstructing the category into its constitutive elements. Ngo and Lee (2007) demonstrate how Southeast Asian American students defy both the model minority image and a countervailing image of them as dropouts and criminals. Indeed, the National Commission on Asian American and Pacific Islander Research in Education (2008) has called for institutions to disaggregate data to "develop our knowledge about ethnic differences within AAPI communities."

The tactic of applauding Asian American educational achievement and bemoaning their victimization by affirmative action plays into the powerful and durable majoritarian narrative of the "model minority," which arose during the Cold War as a strategy to showcase American egalitarianism (Osajima, 2005). This depiction lauded Asian Americans as paragons of success, purporting that they had surmounted discrimination through hard work, education, and adherence to strong family values, rather than resorting to vocal protests and demonstrations (Maeda 2009; 2012). Historian Ellen Wu (2013) contends that a key element of the model minority discourse was to position Asian Americans as "not-Black," that is, as overachievers in contrast to Black underachievement, hard workers in contrast to Black indolence, and as people who play by the rules rather than demanding rights. Although it is often called the model minority myth because of its factual inaccuracy when applied to Asian Americans as a whole (as suggested in the ethnicspecific data cited above), it also performs insidious ideological work by chastising non-Asian 
racial minorities for not having followed the putative model of achievement that Asian Americans have supposedly set. The model minority discourse was deployed to affirm the fundamental fairness of US society. After all, if Asian Americans could overcome discrimination through their own efforts, then African Americans had only themselves--rather than structures of racism--to blame for their predicament. Asian Americans thus appeared as heroic figures in a morality play that was ultimately less about praising them than about vilifying African Americans for their supposed failures and ensuring that the status quo that benefited whites would remain undisturbed. The appearance of the model minority discourse in attacks on affirmative action recapitulates its Cold War role in buttressing notions of fairness and accomplishment. Today, Asian Americans fill the role of victims of unfair discrimination in a narrative that demonizes black and brown people as undeserving, and attempts to return to the pre-affirmative action status quo. Where the model minority discourse once depicted Asian Americans as models of overcoming racism, the Harvard lawsuit portrays them as model victims of unfair discrimination. What remains constant is that in both instances, Asian Americans are deployed as pawns in a struggle to maintain white supremacy.

Given the diversity of Asian Americans, it is unsurprising that they have adopted divergent positions on affirmative action. However, opponents of affirmative action are in the minority among Asian Americans (Robles, 2004). Multiple polls have found consistently that over 6 in 10 Asian Americans support affirmative action, although ethnic-specific polling reveals distinctions. For example, a comprehensive survey by the Inter-University Consortium for Political and Social Research found that $86.1 \%$ of Vietnamese Americans agreed that affirmative action "is a good thing," while only 52.5\% of Indian Americans agreed (Teranishi, n.d.). 
One well-supported Asian American view on affirmative action can be seen an amicus brief to the Supreme Court regarding the Fisher (2013) case, filed on behalf of a coalition of 74 Asian American community groups, non-profits, bar associations, academic units, and student associations. The amicus brief argues that Asian Americans benefit from (rather than being victimized by) race-conscious admissions programs, and both benefit from and contribute to the diverse learning environments fostered by race-conscious admissions.

In their highly influential work on racial formation, Omi and Winant (2015) warn against reducing race to ethnicity, for doing so can obscure ethnic distinctions within racial categories. Despite being lumped together by historical and ongoing racism and coming together through political alliances, Asian Americans continue to exist simultaneously as members of a racial group and members of distinct ethnic groups that vary widely in their access to higher education and jobs. In the case of affirmative action, heeding Omi and Winant's caution means paying careful attention to how treating Asian Americans as a monolithic racial group may harm some of the ethnic groups that constitute it.

\section{Discrimination, Merit, and Affirmative Action}

Given Omi and Winant's (2015) perspective on race and ethnicity, we can understand that issues of racism, white privilege, and power all structure how we think about who deserves to go to college and what admissions rules ought to be (Moses, 2016). From a critical race perspective, racism permeates all social relations, and majoritarian narratives such as claims about meritocracy and upholding the model minority myth, serve to conceal the self-interests of the 
dominant group. And as Bourdieu $(1990 ; 1998)$ has long argued, if the dominant rules of the game begin to disfavor the dominant group, those in power will change the rules in order to maintain privilege. Indeed, we have seen repeatedly how the rules of the game shift in order to maintain the hegemony of dominant groups (Delgado \& Stefancic, 2012; Bourdieu, 1998; Bourdieu \& Passeron, 1990). For example, with Asian American students, on average, outscoring White students on the SAT and ACT, colleges are increasingly de-emphasizing the importance of standardized tests in admissions decisions. In fact, for years, underrepresented students of color and their advocates have been calling for this in the name of fairness, as such tests are widely believed to be biased in favor of dominant groups (e.g., Whites, males), but only recently, when Whites' supremacy on the tests is in question, is there serious change afoot (Guinier, 2015; Lemann, 2000; Sturm \& Guinier, 2001). This connects with how White people's interests supposedly have converged with Asian American people, against affirmative action, resulting in the renewed emphasis on charging selective colleges with discrimination against Asian American applicants. Here critical race theory helps us understand the intentions of the Project on Fair Representation, where its arguments for meritocracy on behalf of Asian American applicants camouflage the primary interest: preserving elite university spaces for White students.

We expect that Harvard will not be found to be discriminating against Asian Americans in admissions, given that the Princeton complaint and other similar complaints have been dismissed already; however, we want to stress that if such discrimination exists, it would be not only unjust but also detrimental to democratic efforts at racial integration in U.S. society (Moses, 2010; Jaschik, 2015). Affirmative action is justified in part because of how it contributes systemically 
to racial diversity among professionals and leaders. As such, Asian Americans from all backgrounds should be included under affirmative action policies. Although certain Asian American heritage groups may no longer be underrepresented in selective institutions of higher education, the issue of underrepresentation should be thought of as one of priority. Affirmative action admissions ought to prioritize underrepresented Asian American students without excluding others. We can justify prioritizing underrepresented students of color (underrepresented Black, Latinx, Native American, and Asian American students - as noted earlier, particularly South and Southeast Asian American students, e.g., with heritage in Laos, Vietnam, the Philippines, or lower castes in India). Both current law and principled justifications for affirmative action based on diversity and social justice allow for distinctions in that manner as admissions officers strive to build a diverse class and provide fair opportunities for all applicants (Moses, 2016; Marin \& Horn, 2008).

In addition to priority, we need to think about emphasis; fair, holistic, race-conscious college admissions processes ought to emphasize the recruitment, enrollment, and retention of all students of color. Just as admissions should prioritize underrepresented Asian American, Black, Latinx, and Native American students, it should emphasize the enrollment of students of color broadly understood. Consider that given the social missions of selective institutions of higher education, race is one factor that may serve as a qualification for college applicants (Moses, 2002; Gutmann, 1999). Social class is another. It makes a qualitative difference for learning, civic education, and other educational outcomes when college students are in class with racially, culturally, and socioeconomically diverse peers (antonio, 2004; Chang, 2001). ${ }^{9}$ 
In the sections that follow, we flesh out our two central arguments further: first, negative action discrimination against Asian American applicants to selective institutions of higher education is wrong, and second, affirmative action policy is not the reason for negative action against Asian Americans.

\section{Discrimination against Asian Americans Is Wrong}

We agree with the plaintiffs in the complaints against Harvard and Princeton that selective colleges should not be discriminating against Asian American applicants. However, our reasoning is quite different from theirs. As we explained above, Asian Americans in the US are far from a monolithic group. Theories of intersectionality reminds us that treating them uniformly results not only in making invisible the diverse histories and experiences Asian American students bring to college, but also in devaluing what other students of color experience. Discrimination is a notoriously tricky concept to understand and apply. Hellman (2008) has analyzed the concept of discrimination in order to explain, in a principled way, how we can understand when discrimination is benign and when it is wrongful. She explains, “Discrimination can be used in a descriptive or moralized way. Descriptively, to 'discriminate' is merely to draw distinctions among people on the basis of the presence of absence of some trait.... When the term discrimination is used in a moralized way, it means to wrongfully draw such distinctions" (p. 13).

We can apply her analyses to affirmative action because she points out, importantly, "where there are limited openings, for jobs or places at school, for example, it is simply not possible to treat one and all the same (emphasis ours). Not everyone can be hired or admitted. 
Thus, we must draw distinctions among the applicants on some basis. The question then becomes, when is such distinction-drawing morally problematic and when is it not?... when does drawing distinctions among people fail to treat those affected as persons of equal moral worth?" (pp. 4, 7). These distinctions give us pause as we again consider majoritarian narratives of meritocracy and the model minority myth as attempts to justify and maintain White supremacy. Hellman argues that we engage in moral wrongdoing when we make demeaning distinctions among people. "To demean," she explains, "is to treat someone in a way that denies her equal moral worth...[it] is not merely to insult but also to put down, to diminish ... It is to treat another as lesser" (p. 29). And, she goes on, "some classifications demean—whether or not the person affected feels demeaned, stigmatized, or harmed" (p. 8). She argues that "when distinctions demean, they wrongfully fail to treat people as moral equals" (p. 31), and concludes, “discrimination is wrong when it demeans" (p. 33). If we accept Hellman's account of the concept of discrimination, we see that affirmative action, as the US Supreme Court upheld in Grutter, is meant to draw distinctions between applicants in order to foster the educational benefits of diversity and democratic aims of equality and social justice. And if we accept critical race notions of counternarratives and intersectionality (Crenshaw, 1991), we recognize the diverse and overlapping ways in which people identify—for example, a student can identify as a woman, Filipina-American, and queer - subsequently creating entry points for us to honor the rich and heterogeneous experiences of people of color. With an eye toward intersectionality, we see that Asian Americans are not constrained to choose race as their sole demographic identifier, given that ethnicity, gender, sexual orientation, socioeconomic background, language, religion, as well as other identity signifiers shape perspectives, experiences, and cultural practices. In that 
regard, Asian Americans from all heritages may contribute to a rich learning environment on campus (Anderson, 2010; Crenshaw, 1991).

Ho (2015) noted that many recent claims of negative action against Asian American are subtle, such as, for example, measuring Asian American college applicants only against other Asian American applicants during admissions review or having cut scores for the reading or writing portions of the SAT. Whether subtle or blatant, negative action cannot be justified. However, Dong (1995) explained the ways in which discrimination (not negative action) - in Hellman's descriptive sense - may be justified related to Asian Americans:

Asian-American leaders therefore are in a double bind. On the one hand, discriminatory college and university admissions lead them to demand that Asian-American and white students receive the same treatment. On the other hand, many remain committed to the belief that often the only way to achieve true equality is to treat minorities and whites differently. ... despite its seeming contradictions, both positions are consistent with the Equal Protection Clause of the Fourteenth Amendment. While educational diversity may justify giving some racial minority groups preferential treatment relative to whites, this goal should never be used to justify giving whites preferential treatment relative to a minority group. Once a racial minority group no longer needs preferential treatment, that group should be allowed to compete on equal terms with whites and should not be singled out for treatment worse than that afforded whites. (p. 1029) And through a critical race lens, we understand that if selective colleges are discriminating against Asian Americans, generally they are doing so not because of a commitment to increase college access for Black, Latinx, or Native American applicants, but in order to maintain the 
disproportionate numbers of White students -- in essence, to maintain White supremacy. Only a meaningful shift in the balance of power from White people to other groups might justify a change in affirmative action target groups (Dong, 1995; Foster, 1993).

Rejected applicants might have cases against Harvard, Princeton, or other elite institutions, but not on the grounds named by their attorneys. Consider, for example, that Adrian Liu (2007-2008) found that Li's complaint against Princeton was warranted, but not for the reason Li gave. Liu argues that Li's case has merit based on a challenge to negative action, not to affirmative action.

Nevertheless, there are prominent objections to our argument that discrimination against Asian Americans in college admissions is wrong. These include the idea that Asian Americans do not need the "special" treatment of affirmative action and that they have exemplary merit for admission into selective higher education or that it is simply not fair that Asian Americans are overrepresented at prestigious institutions of higher education. As such, the arguments go, they ought not to be considered through race-conscious admissions programs. Yet that position reflects a profound misunderstanding of power and privilege and the way they operate in US society. Because Asian American students - particularly those from certain heritage groups - are playing at the very rules put in place by dominant society, and often succeeding, does not mean they do not face marginalization and oppression. Highlighting Asian Americans as "models" for other marginalized groups and has resulted in Ho (2015) calling them the "model victims" (p. 79) and in Lee's (2008) argument that Asian Americans have been "de-minoritized" (p. 130). In fact, quantitatively we can see how the misunderstandings promoted by this objection are based in faulty stereotypes: According to Hing (2004) "Hmong, Laotian and Cambodian Americans 
have the lowest high school attainment levels in the country, lower than that of blacks and Latinos" (para. 17, lines 1-4). Dong (1995) made a complementary historical point:

In education, the Chinese, Japanese, and Filipinos faced de jure segregation in public schools as well as outright exclusion from many colleges and universities... This substantial history of formal discrimination and exclusion carries forward to the present day. The "present effects" of this past treatment - anti-Asian violence, the backlash against the increasing number of Asian-Americans on college campuses, and the "glass ceiling" barring advancement of Asian-Americans to upper-level management positions further substantiate claims of past discrimination. (p. 1046)

Following Dong, positive discrimination in favor of historically underrepresented groups is permissible by democratic standards; negative discrimination is not (Moses, 2002; Gutmann, 1999; Hellman, 2008). We cannot ignore the function of power in how educational opportunities have been and currently are distributed. Recall Bourdieu's (1990; 1998) argument about how the powerful will adjust rules and policies in order to uphold hegemony.

When dominant groups modify the rules in order to preserve their power, we witness slower progress toward achieving racial equity. The critical race perspective of interest convergence explains that change may be gradual because change occurs for people of color only when Whites perceive that such change will benefit Whites (Bell, 1980; Delgado \& Stefancic, 2012). The critical race tenet of majoritarian narratives, which exploits the model minority myth, makes the dominant discourse of meritocracy seem like a common sense, neutral practice when indeed it is not. We argue that a significant example of this is how the Project on Fair Representation, by actively recruiting Asian American plaintiffs, uses them as tools to dismantle affirmative action 
and preserve White supremacy (Bell, 2004). Concomitantly, the practice of negative action against Asian American applicants at elite universities is being criticized publicly. If there were no benefit for White applicants, the Project on Fair Representation would be unlikely to challenge negative action against Asian Americans. ${ }^{10}$ The Project on Fair Representation's attempts to dismantle the solidarity of people of color by appealing to Asian Americans as allies in the fight against affirmative action is not only a bid to create a false interest convergence between Asian American and White students, but a move to preserve the majoritarian narrative of meritocracy, and subsequently, the politics of resentment.

The falsity of this interest convergence can be shown in two ways, through the unproven nature of the allegation that it is affirmative action that causes negative action against Asian Americans and through the harmful effects of treating Asian Americans as monolithic (viz., harming underrepresented Asian American students). Both of these points can be encapsulated in the model minority myth - its utility as a divide-and-conquer strategy and its racialization of all Asian ethnic groups within the rubric of success. For these reasons, critical race theorists, have 'doubts about the foundation of moderate/incremental civil rights law.' Thus, without disrespect to the pioneers of civil rights law, critical race legal scholars document the ways in which civil rights law is regularly subverted to benefit whites. (LadsonBillings \& Tate, 1995, p. 62)

Due to the ability of interest groups to co-opt language from affirmative action policies and undermine the intents of the civil rights movement in ways that preserve White supremacy, it is not surprising that some critical race scholars critique affirmative action (see Crenshaw, 1988; 
Delgado, 1991). However, as we discuss in the following section, affirmative action is not an appropriate scapegoat.

\section{Affirmative Action Is Not to Blame}

Those who oppose affirmative action thus are using a false interest convergence on this issue as a wedge between supposedly "meritorious" students of color - Asian Americans - and "other" students of color, specifically Black, Latinx, and Native American students who remain underrepresented within the most selective institutions of higher education. Our analysis reveals how arguments for colleges to view applicants through majoritarian narratives, that is, so-called meritocratic and neutral approaches and the model minority myth, actually uphold the interests of White people to procure spots at selective institutions. The idea here is to use racial politics to pit racial groups against each other. And, affirmative action opponents like Blum aim to cloud the real issue of inequality of access and opportunity in higher education: the historical preferences that selective colleges and universities have displayed for affluent students, White students, legacy students, and middle class students, all groups whose privilege has compounded over the years, thereby advantaging them in K-12 schools (Lareau, 2001), college entrance examinations, leadership and community service opportunities, and special "talents" (Guinier, 2015; Howe, 2015). Institutions of higher education can point to such students' "merit" to justify the disparities in admission, enrollment, retention, and graduation, and to challenge the fairness of affirmative action policies.

Yet, affirmative action is one modest policy mechanism to promote equality of access and opportunity in higher education. Understood broadly, it underscores the idea that minoritized 
student identity categories such as race, ethnicity, culture, language, social class, gender, gender identity, immigration status, sexual orientation, ability, veteran status, and age constitute legitimate qualifications for admission to college. Because selective institutions of higher education have a social mission to educate professionals, artists, and officeholders for effective leadership and service in a multicultural society, students need to be educated in diverse, integrated contexts (Moses, 2002, 2010; Anderson, 2010; Gutmann, 1999). The social science literature on the educational benefits of diversity provides ample evidence that we all learn, generate ideas, innovate, problem-solve, and think critically much better when we learn in educational contexts rich in diversity (antonio et al., 2004; Chang, 2001; Garces, 2015; Levine \& Stark, 2015). Indeed, students' intersectional identities kindle the potential for designing and enacting robust learning spaces.

It is cynical and disingenuous for right-wing organizations like the Project on Fair Representation to recruit and use Asian Americans to fight against affirmative action. In so doing, they are fanning the flames of resentment between different groups of students of color. From a critical race theory perspective, we understand that this politics of resentment has the ultimate aim of preserving White privilege in selective higher education. As such, we conclude that affirmative action is not the culprit in the controversy over Asian Americans and negative action; White supremacy is.

Conclusion: The Common Enemy of People of Color When asked in a recent interview, "Are there no grounds for celebrating improvement in race relations?" Eddie Glaude made a relevant point: 
As long as we view equality as a kind of charitable enterprise, something white folks give to other folks, we're always going to be behind the eight ball. The goal is for every human being to be afforded dignity and standing. And white people aren't the measure for that. (Luscombe, 2016, p. 130)

Anti-affirmative action movements serve as larger projects of White supremacy, notwithstanding how these campaigns hold up Asian Americans as the wronged race.

A large number of Asian American groups support affirmative action; they refuse to be divided and do not want to be exploited or used against affirmative action (Asian American Center for Advancing Justice, 2012; Matsuda, 1996). Like civil rights groups before them, they recognize that the real enemy of equal opportunity for Asian Americans and all people of color is White supremacy. In this article, we have tried to make the case that race-conscious affirmative action is not the reason for possible discriminatory treatment of Asian American applicants in selective higher education admissions processes. In that vein, Nakagawa explains, "Not only are Asians used as a wedge to break up anti-racist coalitions, they're also useful as a shield against being accused of racism when you do something like attack affirmative action" (Hing, 2014, para. 15, lines 5-8). As evidenced by the Amicus Brief submitted by the Asian American Center for Advancing Justice (2012) supporting the University of Texas' use of affirmative action, a broad coalition is resisting the politics of resentment. Such critical perspectives by Asian Americans who support affirmative action in the name of justice are critical for a more nuanced understanding of affirmative action debates. 
Asian Americans as a broad group may not be underrepresented at selective institutions of higher education (even as subgroups remain underrepresented), but they are underrepresented in leadership, offices, and professional positions even though they attend college at high rates. Using Asian American students and stereotypical (mis)perceptions of a "model minority" to drive a wedge between people of color around the issue of affirmative action policy demonstrates an individualistic political perspective that deeply misunderstands the nature of racial oppression (Moses, 2002; Guinier \& Torres, 2002; Matsuda, 1996). The focus on individual student admissions obfuscates deep systemic issues within selective colleges. Critical race perspectives on Asian American students who do not fit the "model minority" stereotype counteract the insidious, incorrect perspective that all Asian American students achieve in traditional academic ways (Stovall, 2014).

As such, we hope our examination herein has challenged not only the stereotypical received wisdom about the Asian American "model" students who are wronged by affirmative action programs for other students of color (Lee, 2008), but also the ideas that "Asian Americans" comprise a monolithic group and negative action against them in favor of White students is somehow not discriminatory. The fact is that "Asian Americans" have diverse social and educational experiences. And many Asian Americans benefit from affirmative action policies (CARE, 2008; Chin, Cho, Kang, \& Wu, 1996). Given the inevitable public discussion about the Harvard lawsuit and Department of Justice investigation, race-conscious policies like affirmative action need to be supported. We can and should resist cynical racial politics of resentment. And we should question the practice of negative action while at the same time support affirmative action. 
References

Alexander, M. (2012). The new Jim Crow: Mass incarceration in the age of colorblindness. New York: The New Press.

Anderson, E.S. (2010). The Imperative of Integration. Princeton: Princeton University Press.

Andrews, D.J.C., \& Tuitt, F. (2013). Contesting the myth of a 'Post Racial' era: The continued significance of race in U.S. education. New York: Peter Lang Publishing.

antonio, a.1. Chang, M.J. Hakuta, K., Kenny, D.A., Levin, S., \& Milem, J.F. (2004). Effects of racial diversity on complex Thinking in College Students." Psychological Science 15(8):507-10.

Asian American Center for Advancing Justice. (2012). Brief of amici curiae members of Asian American Center for Advancing Justice, et al. in support of respondents. http://www.advancingjustice.org/sites/default/files/2012_08_Fisher_Brief.pdf

Asian American Coalition for Education. (2016). Complaint of the Asian American Coalition for Education v. Yale University, Brown University, and Dartmouth College for Unlawful Discrimination Against Asian-American Applicants in the College Admissions Process. http://asianamericanforeducation.org/wpcontent/uploads/2016/05/Complaint_Yale_Brown_Dartmouth_Full.pdf

Banning, M.E. (2006). The politics of resentment. JAC, 26(1-2):67-101. http://www.jaconlinejournal.com/archives/vol26.1-2/banning-politics.pdf

Bell, D.A. (1980). Brown v. Board of Education and the interest convergence dilemma. Harvard Law Review, 93:518-533.

Bell, D.A. (2004). Silent covenants: Brown v. Board of Education and the unfulfilled hopes for racial reform. New York: Oxford University Press.

Bernhard, M.P. \& Delwiche, N.J. (2015). Groups file federal complaint alleging discrimination in Harvard admissions process. The Harvard Crimson. May 16, 2015. http://www.thecrimson.com/article/2015/5/16/complaint-federal-harvard-admissions/

Bonilla-Silva, E. (2010). Racism without racists: Color-blind racism and racial inequality in contemporary America. Lanham, MD: Rowman \& Littlefield. 
Bourdieu, P. (1998). The state mobility: Elite schools in the field of power. Palo Alto: Stanford University Press.

Bourdieu, P. \& Passeron, J-L. (1990). Reproduction in education, society, and culture, $2^{\text {nd }}$ edition. Thousand Oaks, CA: Sage.

Brown, K. \& Jackson, D.J. (2013).The history and conceptual elements of critical race theory. In The handbook for critical race theory in education, (Ed.), M. Lynn \& A.D. Dixson, 9-22. London: Routledge.

CARE: National Commission on Asian American and Pacific Islander Research in Education. (2008). Asian Americans and Pacific Islanders: Facts, not fiction. Princeton: College Board. https://secure-media.collegeboard.org/digitalServices/pdf/professionals/asian-americans-andpacific-islanders-facts-not-fiction.pdf

CBS. (2014). "Affirmative action lawsuits hit Harvard and UNC." http://www.cbsnews.com/news/affirmative-action-lawsuits-hit-harvard-and-unc/

Chang, M.J. (2001). The positive educational effects of racial diversity on campus. In Diversity challenged: Evidence on the impact of affirmative action, (Ed.), G. Orfield, 175-186. Cambridge: The Civil Rights Project and Harvard Education Publishing Group.

Chin, G., Cho, S., Kang, J., \& Wu, F. (1996). Beyond self-interest: Asian Pacific Americans toward a community of justice. A policy analysis of affirmative action. Asian Pacific American Law Journal, 4:129-162.

Collins, P.H. (2009). Another kind of public education: Race, schools, the media, and democratic possibilities. Boston: Beacon Press.

Crenshaw, K.W. (1988). Race, reform, and retrenchment: Transformation and legitimation in antidiscrimination law. Harvard Law Review, 101(7):1331-1387.

Crenshaw, K.W. (1991). Mapping the margins: Intersectionality, identity politics, and violence against women of color. Stanford Law Review, 43(6):1241-1299.

Delgado, R. (1991). Affirmative action as a majoritarian device: Or, do you really want to be a role model? Michigan Law Review 86:1222-1231.

Delgado, R., \& Stefancic, J. (2012). Critical race theory, $2^{\text {nd }}$ edition. New York: New York University Press. 
Donahoo, S. (2008). Reflections on race: Affirmative action policies influencing higher education in France and the United States. Teachers College Record 110(2):251-77.

Dong, S. (1995). "Too many Asians": The challenge of fighting discrimination against AsianAmericans and preserving affirmative action. Stanford Law Review, 47(5):1027-1057.

Espenshade, T.J. \& Chung, C.Y. (2005). The opportunity cost of admission preferences at elite universities. Social Science Quarterly, 86 (2):293-305.

https://www.princeton.edu/ tje/files/webOpportunity $\% 20$ Cost $\% 20$ of $\% 20$ Admission $\% 20$ Prefere nces\%20Espenshade\%20Chung\%20June\%202005.pdf

Espenshade, T.J. \& Radford, A.W. (2009). No longer separate, not yet equal: Race and class in elite college admission and campus life. Princeton: Princeton University Press.

Espiritu, Y.L. (1993). Asian American panethnicity: Bridging institutions and identities. Philadelphia: Temple University Press.

Fisher v. University of Texas at Austin, 133 S. Ct. 2411 (2013).

Foster S., (1993). Difference and equality: A critical assessment of the concept of "diversity," 105 Wis. L. Rev.:126-27.

Franklin, D.R. \& Zwickel, S.W. (2018, January 24). Experts disagree on motivation for DOJ Harvard probe. The Harvard Crimson. http://www.thecrimson.com/article/2018/1/24/motivations-DOJ-Harvard-probe/

Garces, L.M. (2015). "Brief of 823 Social Scientists as Amici Curiae in Support of Respondents." On Writ of Certiorari to the United States Court of Appeals for the Fifth Circuit, Fisher v. The University Texas-Austin, et al. (No. 14-981, 2015).

Gibson, C. \& Jung, K. (2002). Historical census statistics on population totals by race, 1790 to 1990, and by Hispanic origin, 1970 to 1990,. United States Census Bureau, Population Division, Working Paper No. 56.

Grutter v. Bollinger, 539 U.S. 306 (2003).

Guinier, L. (2015). The tyranny of the meritocracy: Democratizing higher education in America. Boston: Beacon Press. 
Guinier, L., \& Torres, G. (2002). The miner's canary: Enlisting race, resisting power, transforming democracy. Cambridge: Harvard University Press.

Gutmann, A. (1999). Democratic education. Princeton: Princeton University Press.

Harvard University Not Fair. (n.d.). Were you denied admission to Harvard? http://harvardnotfair.org

Haurwitz, R.K.M. (2017, March 2). Affirmative action in UT admissions faces new legal challenge. Austin American-Statesman. http://www.mystatesman.com/news/state--regional-govt-politics/affirmative-action-admissions-faces-new-legalchallenge/dXzUDqUuVtaNuHZUe5cCgK/

Hing, B.O. (1994). Making and remaking Asian America through immigration policy, 18501990. Palo Alto: Stanford University Press.

Hing, J. (2014). Wanted: Disgruntled Asian-Americans to attack affirmative action. Colorlines. April 25, 2104. http://www.colorlines.com/articles/wanted-disgruntled-asian-americans-attackaffirmative-action

Ho, S. (2015). A critique of the motivations behind negative action against Asian Americans in U.S. universities: The model victims. 5.2 Colum. J. of Race and L.:79-99.

Hoeffel, E., et al. (2012). The Asian population: 2010, Census Briefs. Government Printing Office.

Jaschik, S. (2015). Anti-Asian bias claim rejected. InsideHigherEd, September 24, 2015. https:/www.insidehighered.com/news/2015/09/24/ocr-clears-princeton-anti-asiandiscrimination-admissions

Kang, J. (1996). Negative action against Asian Americans: The internal instability of Dworkin's defense of affirmative action. 31 Harv. C.R.-C.L L. Rev.:1-47.

Kao, G. (1995). Asian Americans as model minorities? A look at their academic performance. American Journal of Education 103(2): 121-159.

Kennedy, R. (2013). For discrimination: Race, affirmative action, and the law. New York: Vintage. 
Kever, J. (2008). White sugarland teen sues UT over admissions policy. Houston Chronicle, April 8, 2008. http://www.chron.com/life/mom-houston/article/White-Sugar-Land-teen-sues-UTover-admissions-rule-1678257.php

Kidder, W.C. (2006). Negative action versus affirmative action: Asian Pacific Americans still caught in the crossfire. 11 Mich. J. of Race \& L.:605-624.

Kim, R.S. (2011). The quest for statehood: Korean immigrant nationalism and U.S. Sovereignty, 1905-1945. Oxford, UK: Oxford University Press.

Lee, S.S. (2008). The de-minoritization of Asian Americans: A historical examination of the representations of Asian Americans in affirmative action admissions policies at the University of California. 15 Asian Am. L.J.:129-152.

Lee, S.J. (1996). Unraveling the "model minority" stereotype: Listening to Asian American youth. New York: Teachers College Press.

Lemann, N. (2000). The big test: The secret of history of the American meritocracy. New York: Farrar, Strauss, \& Giroux.

Levine, S.S. \& Stark, D. (2015). Diversity makes you brighter. The New York Times, December 9, 2015: A35.

Liptak, A. (2016). Supreme Court upholds affirmative action program at University of Texas. The New York Times, June 24, 2016. http://www.nytimes.com/2016/06/24/us/politics/supreme-court-affirmative-action-university-oftexas.html? $\_$r=0

Liu, A. (2007-2008). Affirmative action and negative action: How Jian Li's case can benefit Asian Americans.13 Mich. J. Race \& L.:391-431.

Liu, M. et al. (2008). The Snake Dance of Asian American Activism: Community, Vision, and Power. Lanham, MD: Lexington.

Lynn, M., Jennings, M.E., \& Hughes, S. (2013). Critical race pedagogy 2.0: Lessons from Derrick Bell. Race Ethnicity and Education, 16(4):603-628.

Luscombe B. (2016). 9 Questions, Eddie S Glaude, Jr. Time, February 22-29, 2016, 130.

Maeda, D. (2012). Rethinking the Asian American movement. New York: Routledge. 
Maeda, D. (2009). Chains of Babylon: The rise of Asian America. Minneapolis: University of Minnesota Press.

Marin, P. \& Horn, C. L. (2008). Realizing Bakke's legacy: Affirmative action, equal opportunity, and access to higher education. Sterling, VA: Stylus.

Matsuda, M.J. (1996). Where is your body? And other essays on race, gender, and the law. Boston: Beacon Press.

McCloskey, S. (2014). UNC sued for use of race in admissions.” The Progressive Pulse. http://pulse.ncpolicywatch.org/2014/11/17/unc-sued-for-use-of-race-in-admissions/

Moses, M.S. (2016). Living with moral disagreement: The enduring controversy about affirmative action. Chicago: University of Chicago Press.

Moses, M.S. (2010). Moral and instrumental rationales for affirmative action in five national contexts. Educational Researcher, 39(3):211-228.

Moses, M.S. (2002). Embracing race: Why we need race-conscious education policy. New York: Teachers College Press.

Moses, M.S., \& Chang, M.J. (2006). Toward a deeper understanding of the diversity rationale. Educational Researcher, 35(1):6-11.

Mulhere, K. (2014). Lawsuits allege affirmative action violations. InsideHigherEd. November 18, 2014. https://www.insidehighered.com/news/2014/11/18/lawsuits-allege-affirmative-actionviolations

Murray, C. (2012). At the Ivies, Asians are the new Jews. American Enterprise Institute. https://www.aei.org/publication/at-the-ivies-asians-are-the-new-jews/

National Asian American Survey. (2015). http://www.advancingjustice-la.org/blog/nationalasian-american-survey-reports-asian-americans-overwhelmingly-supportaffirmative\#.VoNqEZMrJMU

National Commission on Asian American and Pacific Islander Research in Education. (2008). Asian Americans and Pacific Islanders: Facts, not fiction: Setting the record straight. New York: College Board. 
Ngo, B. \& Lee, S.J. (2007). Complicating the Image of Model Minority Success: A Review of Southeast Asian American Education. Review of Educational Research, 77(4):415-453.

Omi, M. \& Winant, H. (2015). Racial formation in the United States. New York: Routledge.

Osajima, K. (2005). Asian Americans as the model minority: An analysis of the popular press image in the 1960s and 1980s. A companion to Asian American studies, 215-225.

Park, J.J. \& Liu, A. (2014). Interest convergence or divergence? A critical race analysis of Asian Americans, meritocracy, and critical mass in the affirmative action debate. The Journal of Higher Education, 85(1):36-64.

Poon, O.A. (2009). Haunted by negative action: Asian Americans, admissions, and race in the "colorblind era." Harvard University Asian American Policy Review, 18: 81-90.

Project on Fair Representation. (n.d.). Cases. https://www.projectonfairrepresentation.org/cases/

Regents of Univ. of Cal. v. Bakke, 438 U.S. 265, 407 (1978).

Robles, R. (2004). Articulating race-Asian American neoconservative renditions of equality: An analysis of the Brian Ho lawsuit. AAPI Nexus: Asian Americans \& Pacific Islanders Policy, Practice and Community, 2(1):77-104.

Sakamoto, A., Goyette, K.A., \& Kim, C. (2009). Socioeconomic attainments of Asian Americans. Annual Review of Sociology, 35 (2009):255-276.

Sohi, S. (2014). Echoes of mutiny: Race, surveillance, and Indian anticolonialism in North America. Oxford: Oxford University Press.

Stovall, D. (2013). "Killing you is justice:" Trayvon Martin as metaphor for the continual disposability of Black life in the eyes of the law. In K. J. Fasching-Varner et al. (Eds)., Trayvon Martin, race, and American justice, 9-13.

Students for Fair Admissions. (n.d.). http://studentsforfairadmissions.org/wpcontent/uploads/2014/11/SFFA-v.-Harvard-Complaint.pdf and http://studentsforfairadmissions.org/wp-content/uploads/2014/11/SFFA-v.-UNC-Complaint.pdf

Sturm, S. \& Guinier, L. (2001) Who's qualified? Boston: Beacon Press. 
Taylor, E., Gillborn, D., \& Ladson-Billings, G. (Eds.). (2009). Foundations of critical race theory in education. New York: Routledge.

Takagi, D. (1993a). Asian Americans and racial politics: A postmodern paradox. Social Justice, 20(1-2):115-128.

Takagi, D. (1993b). The retreat from race: Asian-American admissions and racial politics. New Brunswick: Rutgers University Press.

Teranishi, R. (n.d.) The attitudes of Asian Americans toward affirmative action. National Commission on Asian American and Pacific Islander Research on Education.

http://care.gseis.ucla.edu/care-reports/

Teranishi, R., Behringer, B., Grey, E., \& Parker, T. (2009). Critical Race Theory and Research on Asian Americans and Pacific Islanders in Higher Education. New Directions for Institutional Research 142: 57-68.

Unz, R. (2012). The myth of American meritocracy. The American Conservative, December 2012:14-51.

UT Not Fair. (n.d.). Were you rejected from the University of Texas at Austin? https://utnotfair.com/

Wu, E.D. (2013). Color of success: Asian Americans and the origins of the model minority. Princeton: Princeton University Press.

Endnotes

${ }^{1}$ See http://harvardnotfair.org/legal-issues/.

${ }^{2}$ Herein by the term "Asian American," we mean Americans of Asian descent including people with Asian Indian, Cambodian, Chinese, Filipino, Guamanian, Hmong, Japanese, Korean, Laotian, Pacific Islander, Samoan, Taiwanese, Thai, or Vietnamese heritage.

${ }^{3}$ We acknowledge that this is a contested term. All people have "color." Herein we use the terms "students of color" and "people of color" to signify currently racialized people in the US, for lack of a term that better identifies this group.

${ }^{4}$ In fact, the lawsuits name discrimination against both Asian American and White applicants.

${ }^{5}$ See, as examples of such simplistic understandings, Unz's (2012) and Murray's (2012) arguments. 
${ }^{6}$ We use the term "Latinx" to represent groups with Caribbean, Central American, Mexican, and South American descent. This term is more inclusive and honoring of intersectionality than other terms commonly used, such as "Hispanic," "Latino," or "Latin@," which uphold, respectively, the Spanish language, masculine hegemony, and the gender binary.

${ }^{7}$ While the Harvard lawsuit is pending, the 2006 Civil Rights complaint against Princeton lodged by a Chinese-American student who had been waitlisted was dismissed in September 2015. A 2015 Civil Rights complaint against Harvard lodged by a coalition of Asian American groups was dismissed as well (though they revised the complaint and submitted it as an Amicus Brief in Fisher v. University of Texas in 2015).

${ }^{8}$ According to Gibson and Jung (2002), the 1950 decennial census reported the Asian population as 321,033 , comprising $0.2 \%$ of the total population. This classification included only Japanese, Chinese, and Filipinos, the three largest Asian ethnic groups at the time. In the 1980 census, the racial category "Asian and Pacific Islander" appeared for the first time, adding Korean, Hawaiian, Vietnamese, Asian Indian, Guamanian and Samoan. The 2010 census question on race included check boxes for six Asian groups - Asian Indian, Chinese, Filipino, Japanese, Korean, and Vietnamese - along with a box for "Other Asian," with a prompt for detailed responses such as "Hmong, Laotian, Thai, Pakistani, Cambodian, and so on." From these responses, the Census Bureau tabulated data on 24 specific Asian groups plus "Other Asian, not specified" (Hoeffel, 2012).

${ }^{9}$ We understand that there is no guarantee that students of color will yield diversity of thought, but it is more likely if the student body is racially and culturally diverse (Moses, 2006; Anderson, 2010).

${ }^{10}$ Recall that we put aside the empirical question of whether elite colleges and universities are in fact using negative action against Asian American applicants. We are not arguing that they are; empirical research is needed to ascertain that. Instead, we are supporting our argument that they should not be using negative action against Asian American applicants. 